\title{
JAK2 Gene Rearrangement
}

National Cancer Institute

\section{Source}

National Cancer Institute. JAK2 Gene Rearrangement. NCI Thesaurus. Code C157572.

A molecular abnormality indicating rearrangement of the JAK2 gene. 